Faculdade de Economia da Universidade de Coimbra

Grupo de Estudos Monetários e Financeiros (GEMF)

Av. Dias da Silva, 165 - 3004-512 COIMBRA, PORTUGAL

gemf@fe.uc.pt

http://gemf.fe.uc.pt

CARLOS FONSECA MARINHEIRO

Has the Stability and Growth Pact

stabilised? Evidence from a panel of 12

European countries and some implications

for the reform of the Pact

ESTUDOS DO GEMF

N. ${ }^{0} 2$

2005

PUBLICAÇÃO CO-FINANCIADA PELA FUNDAÇÃO PARA A CIÊNCIA E TECNOLOGIA

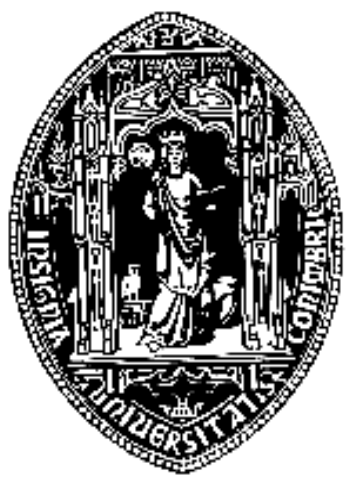




\title{
Has the Stability and Growth Pact stabilised? Evidence from a panel of 12 European countries and some implications for the reform of the Pact
}

\author{
Carlos José Fonseca Marinheiro* \\ Faculdade de Economia and $\mathrm{GEMF}^{+}$ \\ Universidade de Coimbra \\ marinheiro@fe.uc.pt
}

January 2005

\begin{abstract}
Ever since its inception EMU has been subject to controversy. The fiscal policy rules embedded in the Treaty on European Union, and clarified in the Stability and Growth Pact (SGP), are probably the most contentious. The SGP is being accused of being too rigid and of forcing pro-cyclicality in fiscal policy. We test the impact of the SGP rules on the cyclical properties of fiscal policy for a panel of 12 European countries. We conclude that contrary to what might have been expected the euro fiscal rules have reinforced the counter-cyclicality of fiscal policy. However, the results also show that the SGP is not being applied symmetrically over the cycle, leading to insufficient fiscal consolidation during economic upswings. This explains the recent difficulties of Portugal, Germany and France in complying with SGP requirements. Based on these conclusions we argue for the creation of independent national technical committees that would define an appropriate deficit target on an annual basis.
\end{abstract}

Keywords: Fiscal policy, stabilisation, EMU, Stability and Growth Pact reform. JEL codes: E62, H62

\footnotetext{
" Paper prepared for the 2004 CESifo-LBI Conference on "Sustainability of Public Debt", October 22-23 2004, Munich. Correspondence to Faculdade de Economia, Universidade de Coimbra, Av. Dias da Silva, 165, 3004-512 Coimbra, Portugal. E-mail: marinheiro@fe.uc.pt. URL: http://www4.fe.uc.pt/carlosm.

+ GEMF - Grupo de Estudos Monetários e Financeiros.
} 


\section{Introduction}

The completion of EMU in Europe, with the introduction of the single currency - the euro- in 1999 has greatly affected the conduct of economic policy in the twelve participating member states. The only traditional short-term macroeconomic instrument that remains in the control of national authorities is fiscal policy. Consequently, fiscal policy has gained new responsibilities with EMU, but at the same time the Stability and Growth Pact (SGP) constrains it operation. Fiscal policy must now provide output smoothing, especially the smoothing of asymmetric shocks, and contribute to attaining price stability and external balance. These new objectives are particularly important for the case of small countries out of synchrony with the rest of the monetary union and require a flexible fiscal policy. This paper therefore aims at evaluating the actual cyclical properties of fiscal policy and its implications for the ongoing debate on the reform of the SGP.

It has been argued that the fiscal rules imposed by the SGP lead to the need to override the working of the automatic fiscal stabilisers, resulting in a pro-cyclical fiscal policy. This paper evaluates such claim using empirical evidence drawn from a panel of 12 European countries for the period 1980-2003. Section II reviews the economics of fiscal policy in Economic and Monetary Union (EMU). It briefly reviews the role of fiscal policy in the EMU setup. Section III presents the empirical evidence regarding the cyclical responsiveness of fiscal policy to the cycle. The evidence is based on a panel data analysis and distinguishes the overall reaction of the budget from discretionary actions. Based on the conclusions of the empirical results, section IV takes the early non-SGP compliant countries (Portugal, Germany, and France) as case-studies, and tries to find out whether the exceeding of the 3\% threshold for the deficit was due to an asymmetric enforcement of SGP rules over the cycle. Section V derives some implications for the ongoing debate on the reform of the SGP rules. The conclusions are discussed in Section VI.

\section{Fiscal Policy in EMU}

In a traditional Keynesian framework different short-term objectives are achieved by making use of different instruments: fiscal policy is responsible for the stabilisation of the business cycle; monetary policy tries to maintain price stability and might also help to stabilise the business cycle; and the exchange rate policy helps to stabilise external balance. Since the last two instruments have been lost in euro-area countries, fiscal policy obligations have increased. For euro-area countries, fiscal policy has to achieve three objectives: a) the stabilisation of the business cycle, especially the stabilisation of asymmetric demand shocks; b) help to stabilise inflation, especially in small countries which are out of synchrony with the rest of the monetary union; and, c) the attainment of external balance. 
Compared with the pre-EMU situation, fiscal policy now plays an extended role in the smoothing of output shocks, particularly idiosyncratic demand shocks. Even if the ECB pursues some degree of output smoothing, the single monetary policy could not be used to smooth asymmetric shocks. ${ }^{1}$ Consequently, most of the short-term stabilisation effort relies on fiscal policy. Moreover, comparing the euro-area with other successful currency unions, namely, with the USA, we can say that fiscal policy is particularly relevant for the smoothing of shocks in the euro-area as this latter currency area lacks most of the usual responses to asymmetric shocks, that is, labour mobility within the area, flexibility of wages and prices, and finally some sort of insurance mechanism, like an automatic mechanism for transferring fiscal resources to the affected country(ies)/region(s).

Negative demand shocks cause a fall in both the output gap and inflation. When there is a symmetric demand shock which affects the entire euro-area, both the centralised monetary policy and the automatic fiscal stabilisers could be used to smooth it out. However, the common monetary policy cannot be used to smooth out asymmetric shocks. The monetary policy only reacts when there is a change in the euro-area inflation and output gap. If the shock only affects (a small) part of the area, the aggregate statistics do not change (much), and so the ECB does not react. This is particularly true for the case of the small countries of the euro-area. For example, a 1\% fall in the German GDP has a much larger impact in the euro-area aggregate than a 1\% drop in the Portuguese GDP. Thus a small country that is out of synchrony with the rest of the monetary union suffers from the perverse effects of the single monetary policy: its inflation rate and output gap decline, but as the aggregate euro-area figures do not change, the ECB does not adjust its monetary policy. As a result, a small country affected by a negative asymmetric demand shock faces an interest rate that is higher than it would be if it were a country large enough to influence the monetary union average. ${ }^{2}$ Such shocks must therefore be smoothed by the operation of fiscal policy, and by an increase in net exports. Fiscal policy is therefore more important than before, when there were national monetary policies, particularly for small countries. ${ }^{3}$

\footnotetext{
${ }^{1}$ Under Article 2 of the ECB Statutes, "without prejudice to the objective of price stability" the ECB supports the general economic objectives of the European Community, namely the goal of a high level of employment. So only if it does not endanger the primary objective of price stability could the ECB pursue the stabilisation of the euro-area output gap.

2 This non-responsiveness of the interest rate increases the real burden of public debt for highly indebted countries.

${ }^{3}$ See Marinheiro (2003) for further details.
} 


\section{III.Empirical evidence on the effective cyclical properties of fiscal policy}

The importance of fiscal policy as a counter-cyclical stabilisation means that it makes sense to see whether fiscal policy has in fact been used in Europe with such considerations in mind. It is also very interesting to find out whether the start of EMU has signalled a shift of fiscal policy towards a more counter-cyclical instrument. For this we will empirically test whether the budget balance has reacted positively to the output gap.

\section{A. The empirical specification}

If fiscal policy were being used as a pure counter-cyclical instrument to dampen the amplitude of the business cycle, that is if the automatic stabilisers are allowed to work freely over the cycle, we should observe a deterioration of the budget balance during recessions and an improvement during upturns. This implies a positive reaction of the budget balance to the output gap, defined as the difference between current and potential output as a fraction of potential output. However, the working of the automatic stabilisers could be counteracted (or reinforced) by discretionary fiscal policy measures. ${ }^{4}$ It is therefore interesting to observe how fiscal policy has been used in practice, and assess the impact of the working of the SGP provisions. We will also assess whether fiscal policy is asymmetric over the cycle, being more relaxed downswings than it is tightened in upswings.

We will try to answer these questions using a panel data econometric approach for 12 European Union countries over the period 1980-2003, estimating the reaction of the fiscal variables to the business cycle, distinguishing automatic reactions from discretionary changes. In practice there are several difficulties in disentangling the automatic fiscal policy variations from discretionary actions. Here we will use the change in cyclically adjusted data as a proxy for discretionary actions. ${ }^{5}$ The source of data (including the cyclically adjusted data and the output gap estimate) is the European Commission (2004), and is available in the AMECO database (30-04-2004 version).

Our basis regression for the overall fiscal policy reaction to cycle is

$$
\Delta \mathrm{B}^{\mathrm{Bal}} \mathrm{Bal}_{\mathrm{it}}=\alpha_{\mathrm{i}}+\beta \cdot \Delta \mathrm{GAP}_{\mathrm{it}}+\mathrm{e}_{\mathrm{it}}
$$

\footnotetext{
${ }^{4}$ For a discussion about the usefulness and desirability of discretionary fiscal policy, see the excellent surveys by Andersen (2001) and Auerbach (2002).

${ }^{5}$ This is the usual practice according to the literature. The use of primary balance instead of the overall budget balance is motivated by the fact that interest payments are not under the control of the fiscal authorities, but simply reflect the evolution of the interest rate and the past accumulation of budget deficits.
} 
and for discretionary fiscal policy reactions

$$
\Delta \operatorname{Prim} . \mathrm{Bal}_{\mathrm{it}}^{\mathrm{CA}}=\alpha_{\mathrm{i}}+\beta \cdot \Delta \mathrm{GAP}_{\mathrm{it}}+\mathrm{e}_{\mathrm{it}}
$$

Where B.Balit denotes the budget balance divided by potential output, for country $i$ in period $t$; Prim.BalcA stands for the cyclically adjusted primary balance as a fraction of potential output, and $\mathrm{GAP}_{\mathrm{t}}$ the output gap defined as the difference between current and potential output, divided by potential output. ${ }^{6} \Delta$ is the difference operator. The parameter $\beta$ gives an index of how cyclical fiscal policy has been in the past. This basis specification is adapted from specifications used by Wyplosz (2002), Auerbach (2002), and Pina (2004). ${ }^{7}$ Following the practice used in this recent literature we will augment those specifications by including the lagged debt ratio. This allows to control for sustainability considerations in the conduct of fiscal policy. We will also estimate similar regressions using public expenditure, and public revenues as dependent variables.

The parameter $\beta$ gives an index of how cyclical fiscal policy has been in the past. If fiscal policy has been counter-cyclical we would expect expenditure to decline, revenues to increase, and as a result the budget balance also increases when the output gap increases, that is when the economy is in growing. Hence we would expect to find a negative $\beta$ coefficient in the revenue equation, and positive coefficients in both the expenditure and the budget balance regressions. To test for asymmetry and for the impact of the introduction of the euro, we will follow Wyplosz (2002) and add adequate interaction terms between the output gap and time dummy variables. To test for asymmetry the gap variable will be interacted with a dummy variable that takes the value 1 when the output gap declines (i.e. in downswings) and 0 otherwise. This allows the gap variable to enter separately when the gap is declining. If in fact fiscal policy is more relaxed in downswings, meaning it has a stronger counter-cyclical reaction to downswings than to upswings, the interacted gap variable has the same sign as the gap itself. To test for the impact of the euro on the cyclical responsiveness of fiscal policy the output gap will be interacted with a dummy variable that takes the value 1 for the period 1999-2003.

\footnotetext{
${ }^{6}$ Potential output is used as a deflator of all variables, instead of actual output, to reduce endogeneity problems and to minimize the influence of current GDP on the evolution of the fiscal ratios. See Bayoumi and Masson (1995) for a similar use.

${ }^{7}$ An alternative specification is proposed by Lane (2003).
} 


\section{B. Empirical results}

Table 1 and Table 2 present the results for the unadjusted fiscal variables and for the cyclically adjusted variables, respectively. Results are obtained allowing for different intercepts for each country using a fixed effects (LSDV) estimator. When using fixed effects, the inference is conditional on the particular set of countries and for the specific time periods observed. ${ }^{8}$ This is precisely our objective. Another possibility would be to estimate the model using random effects. This would avoid the loss of degrees of freedom implied by the use of fixed effects, and the inference would pertain to the large population from which the sample is drawn. However, this technique is only appropriate if we are drawing the $\mathrm{N}$ individuals randomly from a large population. Thus, it is necessary to have a panel representative of the whole population for which we are trying to make inferences. As our population of EU-15 countries is (almost) entirely represented in the sample of 12 European countries, it makes no econometric sense to use a random effects estimator. In short, and in this case, econometric theory clearly points to the use of the fixed effects model.

Column (1) of Table 1 shows the baseline equation for the overall budget balance. According to the estimates the overall budget balance is counter-cyclical: an increase of 1 percentage point (p.p.) in the output gap leads to an increase of 0.38 p.p. in the budget balance as a percentage of potential output. Column (2) adds lagged debt ratio as an independent variable. Lagged debt is statistically significant and positive, which implies that sustainability considerations enter the budget process in European Union countries. This effect is always statistically significant in all the different regressions. The output gap coefficient remains statistically significant and barely unchanged with the introduction of this control. Next, in columns (3) and (4), we use appropriate interaction variables to distinguish the cyclical reaction of the budget balance in different sub-periods related to the introduction of the single currency. Phase I of EMU has started in 1992, with the signing of the Maastrich Treaty which imposes a reference value for the deficit. However, in our view it was only in 1995 that most European countries really started the convergence to the 3\% limit for the deficit. Hence, we subdivide the run-up period into two sub-periods: 1992-1994 and 1995-1999. ${ }^{9}$ It might be expected that the convergence criteria would have led to a less counter-cyclical use of fiscal policy. However, our results do not confirm that claim: the estimated coefficients are positive, but not statistically significant. In fact, when disaggregating the deficit variation into its expenditure and revenue components (last two columns), we can see that expenditure has become countercyclical in the 1995-98 period, but

\footnotetext{
${ }^{8}$ See Baltagi (2001).

${ }_{9}$ Phase II of EMU started only in 1994, and it was clear to participants that phase III would only start on the date limit imposed by Article 121 of the Treaty (1999).
} 
the counter-cyclical properties of revenues fell in the same period. As a result the run up to the single currency had a neutral impact on the counter-cyclical properties of fiscal policy.

Table 1- Sensitivity to cyclical conditions - 12 EU countries1980-2003

\begin{tabular}{|c|c|c|c|c|c|c|c|c|}
\hline \multirow[t]{2}{*}{ Dependent: } & \multicolumn{6}{|c|}{$\Delta$ Budg. Balance } & \multirow{2}{*}{$\begin{array}{c}\Delta \operatorname{Rev} \\
(7)\end{array}$} & \multirow{2}{*}{$\begin{array}{c}\Delta \operatorname{Exp} \\
(8)\end{array}$} \\
\hline & $(1)$ & $(2)$ & (3) & (4) & (5) & $(6)$ & & \\
\hline GAP & $\begin{array}{r}0.383 \\
(3.24)\end{array}$ & $\begin{array}{l}0.315 \\
(2.8)\end{array}$ & $\begin{array}{r}0.238 \\
(1.73)\end{array}$ & $\begin{array}{r}0.271 \\
(2.24)\end{array}$ & $\begin{array}{r}0.078 \\
(0.68)\end{array}$ & $\begin{array}{c}0.05 \\
(0.44)\end{array}$ & $\begin{array}{r}0.407 \\
(3.92)\end{array}$ & $\begin{array}{r}0.357 \\
(1.91)\end{array}$ \\
\hline D92-94*GAP & - & - & $\begin{array}{c}0.14 \\
(1.25)\end{array}$ & - & - & - & - & - \\
\hline D95-98*GAP & - & - & $\begin{array}{c}0.16 \\
(1.01)\end{array}$ & $\begin{array}{r}0.145 \\
(0.93)\end{array}$ & - & $\begin{array}{r}0.206 \\
(1.71)\end{array}$ & $\begin{array}{l}-0.218 \\
(1.26)\end{array}$ & $\begin{array}{l}-0.421 \\
(3.07)\end{array}$ \\
\hline D99-03*GAP & - & - & $\begin{array}{r}0.346 \\
(1.74)\end{array}$ & $\begin{array}{r}0.312 \\
(1.64)\end{array}$ & - & $\begin{array}{r}0.409 \\
(1.34)\end{array}$ & $\begin{array}{l}-0.033 \\
(0.2)\end{array}$ & $\begin{array}{l}-0.441 \\
(1.92)\end{array}$ \\
\hline GAP*Downswing & - & - & - & - & $\begin{array}{r}0.416 \\
(1.97)\end{array}$ & $\begin{array}{r}0.421 \\
(1.99)\end{array}$ & $\begin{array}{l}-0.231 \\
(1.58)\end{array}$ & $\begin{array}{l}-0.654 \\
(2.26)\end{array}$ \\
\hline $\begin{array}{l}\text { D95-98*GAP* } \\
\text { Downswing }\end{array}$ & - & - & - & - & $\begin{array}{r}0.047 \\
(0.09)\end{array}$ & $\begin{array}{l}-0.237 \\
(0.56)\end{array}$ & $\begin{array}{l}-0.173 \\
(0.43)\end{array}$ & $\begin{array}{r}0.055 \\
(0.11)\end{array}$ \\
\hline $\begin{array}{l}\text { D99-03*GAP* } \\
\text { Downswing }\end{array}$ & - & - & - & - & $\begin{array}{r}0.274 \\
(1.51)\end{array}$ & $\begin{array}{l}-0.158 \\
(0.53)\end{array}$ & $\begin{array}{r}0.448 \\
(2.22)\end{array}$ & $\begin{array}{r}0.605 \\
(2.34)\end{array}$ \\
\hline Lagged debt & - & $\begin{array}{r}0.033 \\
(7.91)\end{array}$ & $\begin{array}{r}0.033 \\
(8.51)\end{array}$ & $\begin{array}{r}0.032 \\
(8.38)\end{array}$ & $\begin{array}{r}0.031 \\
(7.13)\end{array}$ & $\begin{array}{c}0.03 \\
(6.8)\end{array}$ & $\begin{array}{l}-0.006 \\
(1.32)\end{array}$ & $\begin{array}{l}-0.036 \\
(9.7)\end{array}$ \\
\hline $\mathrm{R}^{2}$ & 0.16 & 0.239 & 0.252 & 0.25 & 0.261 & 0.267 & 0.259 & 0.304 \\
\hline Wald test joint & $\begin{array}{c}10.48 \\
(0.0)\end{array}$ & $\begin{array}{c}98.52 \\
(0.0)\end{array}$ & $\begin{array}{r}190.2 \\
(0.0)\end{array}$ & $\begin{array}{r}103.8 \\
(0.0)\end{array}$ & $\begin{array}{r}150.5 \\
(0.0)\end{array}$ & $\begin{array}{r}742.1 \\
(0.0)\end{array}$ & $\begin{array}{l}42.37 \\
(0.0)\end{array}$ & $\begin{array}{r}437.1 \\
(0.0)\end{array}$ \\
\hline AR1 test & $\begin{array}{c}0.35 \\
(0.73)\end{array}$ & $\begin{array}{l}-0.65 \\
(0.52)\end{array}$ & $\begin{array}{l}-0.49 \\
(0.63)\end{array}$ & $\begin{array}{l}-0.54 \\
(0.59)\end{array}$ & $\begin{array}{l}-0.86 \\
(0.39)\end{array}$ & $\begin{array}{l}-0.67 \\
(0.0)\end{array}$ & $\begin{array}{l}-0.54 \\
(0.59)\end{array}$ & $\begin{array}{l}-0.09 \\
(0.93)\end{array}$ \\
\hline
\end{tabular}

Notes: In parentheses absolute T-stats (based on robust standard errors) for coefficients and p-values for tests. Estimation method is Least Squared Dummy Variables (LSDV), also known as fixed effects estimator, for a panel of 12 European Union member countries over the period 1980-2003: Austria, Belgium, Denmark, Finland, France, Germany, Ireland, Italy, Netherlands, Portugal, Greece and UK. Countries were selected according to data availability. Observations start in 1986 for Ireland, and in 1988 for Greece. The source of data is the AMECO database, Autumn 2004 version. PCGIVE based calculations including a constant term (omitted). The AR1 test is asymptotically distributed as $\mathrm{N}(0,1)$ under the null of no first order serial correlation. A counter-cyclical fiscal policy implies $\beta_{\mathrm{BBAL}}>0, \beta_{\mathrm{REV}}>0$, and $\beta_{\mathrm{EXP}}<0$.

In order to assess the impact of the introduction of the euro, we interacted the gap variable with a dummy for the $1999-2003$ period. The coefficient of the interacted gap is positive but is not statistically significant. Hence, it appears that the EMU policy rules have reinforced the counter-cyclical properties of fiscal policy. Such reinforcement appears to be 
due to a positive impact of such rules on the counter-cyclicality of expenditure. Conversely, the introduction of the euro appears to have no impact on the cyclical properties of public revenues. The overall cyclical reaction of fiscal policy in the euro period would be obtained by adding the gap coefficient to the interacted gap coefficient. However, as the time series dimension of the euro-period sample is still relatively small and the goodness of fit is not high, we decided to test the impact of the euro directly, in a separate regression distinguishing only the pre from the post-euro period. A more definitive conclusion will thus be based on the analysis of those results, shown in Table 3, below.

Column (5) tests for asymmetry in the reaction of fiscal policy. If fiscal policy is more counter-cyclical in downswings than it is in upswings, leading to a non-balanced budget balance over the cycle, we should observe that the interacted gap is of the same sign as the gap itself. Our results suggest that this has been the case for European countries both in the overall period and in the different sub-periods considered. Fiscal policy tends to be more counter-cyclical in downswings than it is in upswings. Column (6) presents all the different effects in the same regression. 
Table 2- Sensitivity of CA measures to cyclical conditions -12 EU countries 19802003

\begin{tabular}{|c|c|c|c|c|c|c|c|c|}
\hline \multirow[t]{2}{*}{ Dependent: } & \multicolumn{6}{|c|}{$\triangle C A$ Primary Balance } & \multirow{2}{*}{$\frac{\Delta C A \operatorname{Rev}}{(7)}$} & \multirow{2}{*}{$\begin{array}{c}\Delta C A \\
\text { Pr.Exp } \\
(8)\end{array}$} \\
\hline & $(1)$ & (2) & (3) & $(4)$ & (5) & (6) & & \\
\hline$\triangle \mathrm{GAP}$ & $\begin{array}{l}-0.109 \\
(1.93)\end{array}$ & $\begin{array}{l}-0.14 \\
(2.7)\end{array}$ & $\begin{array}{l}-0.179 \\
(2.69)\end{array}$ & $\begin{array}{l}-0.161 \\
(3.08)\end{array}$ & $\begin{array}{l}-0.261 \\
(4.69)\end{array}$ & $\begin{array}{l}-0.25 \\
(4.74)\end{array}$ & $\begin{array}{c}0.163 \\
(0.97)\end{array}$ & $\begin{array}{r}0.409 \\
(2.65)\end{array}$ \\
\hline D92-94* $\Delta$ GAP & - & - & $\begin{array}{r}0.076 \\
(0.45)\end{array}$ & - & - & - & - & - \\
\hline D95-98* $\Delta$ GAP & - & - & $\begin{array}{r}0.006 \\
(0.05)\end{array}$ & $\begin{array}{l}-0.002 \\
(0.01)\end{array}$ & - & $\begin{array}{l}-0.043 \\
(0.42)\end{array}$ & $\begin{array}{l}-0.28 \\
(1.57)\end{array}$ & $\begin{array}{l}-0.234 \\
(1.46)\end{array}$ \\
\hline D99-03* $\Delta$ GAP & - & - & $\begin{array}{r}0.202 \\
(1.49)\end{array}$ & $\begin{array}{r}0.184 \\
(1.31)\end{array}$ & - & $\begin{array}{l}-0.215 \\
(0.71)\end{array}$ & $\begin{array}{l}-0.096 \\
(0.55)\end{array}$ & $\begin{array}{r}0.125 \\
(0.59)\end{array}$ \\
\hline$\Delta \mathrm{GAP}^{*}$ Downswing & - & - & - & - & $\begin{array}{r}0.179 \\
(1.52)\end{array}$ & $\begin{array}{r}0.178 \\
(1.57)\end{array}$ & $\begin{array}{l}-0.396 \\
(1.7)\end{array}$ & $\begin{array}{l}-0.569 \\
(2.6)\end{array}$ \\
\hline $\begin{array}{l}\text { D95-98* }{ }^{*} \text { GAP* } \\
\text { Downswing }\end{array}$ & - & - & - & - & $\begin{array}{l}-0.119 \\
(0.26)\end{array}$ & $\begin{array}{l}-0.045 \\
(0.1)\end{array}$ & $\begin{array}{l}-0.286 \\
(0.71)\end{array}$ & $\begin{array}{l}-0.204 \\
(0.4)\end{array}$ \\
\hline $\begin{array}{l}\text { D99-03* }{ }^{*} \text { GAP* } \\
\text { Downswing }\end{array}$ & - & - & - & - & $\begin{array}{r}0.378 \\
(2.55)\end{array}$ & $\begin{array}{c}0.602 \\
(1.76)\end{array}$ & $\begin{array}{c}0.484 \\
(2.44)\end{array}$ & $\begin{array}{l}-0.133 \\
(0.43)\end{array}$ \\
\hline Lagged debt & - & $\begin{array}{r}0.015 \\
(3.72)\end{array}$ & $\begin{array}{r}0.015 \\
(3.53)\end{array}$ & $\begin{array}{r}0.015 \\
(3.59)\end{array}$ & $\begin{array}{c}0.014 \\
(1.21)\end{array}$ & $\begin{array}{c}0.014 \\
(4.21)\end{array}$ & $\begin{array}{l}-0.007 \\
(1.76)\end{array}$ & $\begin{array}{l}-0.021 \\
(7.19)\end{array}$ \\
\hline$\overline{\mathrm{R}^{2}}$ & 0.025 & 0.049 & 0.055 & 0.054 & 0.066 & 0.068 & 0.15 & 0.205 \\
\hline Wald test joint & $\begin{array}{c}3.71 \\
(0.05)\end{array}$ & $\begin{array}{l}14.19 \\
(0.0)\end{array}$ & $\begin{array}{l}40.99 \\
(0.0)\end{array}$ & $\begin{array}{l}41.04 \\
(0.0)\end{array}$ & $\begin{array}{c}70.67 \\
(0.0)\end{array}$ & $\begin{array}{c}90.71 \\
(0.0)\end{array}$ & $\begin{array}{c}36.11 \\
(0.0)\end{array}$ & $\begin{array}{c}123.9 \\
(0.0)\end{array}$ \\
\hline AR1 test & $\begin{array}{l}-0.49 \\
(0.62)\end{array}$ & $\begin{array}{l}-0.56 \\
(0.58)\end{array}$ & $\begin{array}{l}-0.5 \\
(0.62)\end{array}$ & $\begin{array}{l}-0.53 \\
(0.6)\end{array}$ & $\begin{array}{l}-0.7 \\
(0.49)\end{array}$ & $\begin{array}{l}-0.83 \\
(0.41)\end{array}$ & $\begin{array}{l}-0.73 \\
(0.47)\end{array}$ & $\begin{array}{c}0.352 \\
(0.73)\end{array}$ \\
\hline
\end{tabular}

Notes: See Table 1. Pr. Exp. stands for primary expenditures. A counter-cyclical fiscal policy implies $\beta_{\mathrm{BB} A \mathrm{~L}}>$ $0, \beta_{\text {REV }}>0$, and $\beta$ EXP $<0$.

Table 2 shows the estimated results for the discretionary fiscal policy changes. It has exactly the same structure as Table 1, which we have just discussed. Overall discretionary fiscal policy was pro-cyclical in the $1980-2003$ period. This pro-cyclicality is mostly due to the strong pro-cyclical behaviour of primary expenditure. With regard to asymmetry over the cycle, and especially for the period after 1999, asymmetric behaviour is also observed. For that period, according to column (5) estimates, during upswings the deficit increases by 0.26 times the change in gap, and in downswings the deficit increases as well, by 0.3 times the absolute change in the gap. Thus, in general, discretionary fiscal policy is pro-cyclical in upswings and counter-cyclical in downswings.

With regard to the impact of the euro the results are not very clear since the coefficients are of the opposite sign of the gap variable, but not statistically significant. We will therefore base our conclusions on the results of Table 3. 
Table 3- Impact of the introduction of the euro -12 EU countries 1980-2003

\begin{tabular}{|c|c|c|c|c|}
\hline \multirow[t]{2}{*}{ Dependent: } & \multicolumn{2}{|c|}{$\triangle$ Budg. Balance } & \multicolumn{2}{|c|}{$\triangle C A$ Primary Balance } \\
\hline & $(1)$ & $(2)$ & (3) & $(4)$ \\
\hline$\triangle \mathrm{GAP}$ & - & $\begin{array}{r}0.078 \\
(0.71)\end{array}$ & - & $\begin{array}{l}-0.268 \\
(4.17)\end{array}$ \\
\hline D80-98* $\Delta \mathrm{GAP}$ & $\begin{array}{c}0.28 \\
(2.46)\end{array}$ & - & $\begin{array}{l}-0.161 \\
(3.36)\end{array}$ & - \\
\hline D99-03* $\Delta$ GAP & $\begin{array}{c}0.585 \\
(2.87)\end{array}$ & - & $\begin{array}{c}0.023 \\
(0.15)\end{array}$ & - \\
\hline D80-98* $\Delta$ GAP $^{*}$ Downswing & - & $\begin{array}{r}0.415 \\
(1.98)\end{array}$ & - & $\begin{array}{c}0.239 \\
(1.65)\end{array}$ \\
\hline D99-03* $\Delta$ GAP*Downswing & - & $\begin{array}{c}0.689 \\
(1.98)\end{array}$ & - & $\begin{array}{r}0.361 \\
(1.52)\end{array}$ \\
\hline Lagged debt & $\begin{array}{c}0.033 \\
(8.08)\end{array}$ & $\begin{array}{r}0.031 \\
(7.28)\end{array}$ & $\begin{array}{r}0.015 \\
(3.91)\end{array}$ & $\begin{array}{r}0.029 \\
(7.34)\end{array}$ \\
\hline $\mathrm{R}^{2}$ & 0.248 & 0.261 & 0.054 & 0.123 \\
\hline Wald test joint & $\begin{array}{c}99.62 \\
(0.0)\end{array}$ & $\begin{array}{r}123.1 \\
(0.0)\end{array}$ & $\begin{array}{c}40.25 \\
(0.0)\end{array}$ & $\begin{array}{c}88.31 \\
(0.0)\end{array}$ \\
\hline AR1 test & $\begin{array}{l}-0.48 \\
(0.63)\end{array}$ & $\begin{array}{l}-0.87 \\
(0.39)\end{array}$ & $\begin{array}{l}-0.53 \\
(0.60)\end{array}$ & $\begin{array}{l}-1.33 \\
(0.18)\end{array}$ \\
\hline
\end{tabular}

Notes: See Table 1. A counter-cyclical fiscal policy implies $\beta_{\mathrm{BBAL}}>0, \beta_{\mathrm{REV}}>0$, and $\beta_{\mathrm{EXP}}<0$.

Table 3 tests explicitly, and in isolation, the impact of the euro on the cyclical properties of fiscal policy and on the asymmetry of its use over the cycle. As shown in column (1) the overall reaction of the budget balance to the cycle has increased from 0.28 in the 1980-1998 period to 0.585 in the post 1999 period. Consequently, it appears that the EMU rules have reinforced the counter-cyclical properties of fiscal policy, confirming the results in Table 1. This reinforcement is due to a change in the behaviour of discretionary fiscal policy, which has evolved from a clear pro-cyclical behaviour in the period pre-EMU to a broadly neutral cyclical behaviour in the euro period.

The asymmetric reaction of fiscal policy to the business cycle in the 1980-1998 period appears to have been reinforced in the EMU period. This implies that fiscal policy is now more responsive to cyclical downswings than before. Contrary to what might have been expected, discretionary fiscal policy is found to be neutral to counter-cyclical in downturns in the 1999-2003 period. ${ }^{10}$ Using a different methodology and data sample, we reach a similar

\footnotetext{
10 The conclusion of neutral fiscal stance is due to the non-statistically significant positive coefficient on the interacted gap for the 1999-2003 period.
} 
conclusion to the OECD (2003). Yet our results imply, too, that the SGP provisions are not being enforced symmetrically over the cycle, which is the main source of concern with its formulation, as argued below.

All in all, it appears that the SGP has helped to reinforce the cyclical properties of fiscal policy, leading to greater stabilisation of cyclical fluctuations. However, some care is needed when interpreting these results, as they are based on a very short time period that is less than a full business cycle. ${ }^{11}$ Moreover, the results are a panel basis estimation, meaning they are valid for the overall ensemble of countries, but not necessarily to each of them individually. Table 4 presents a summary of our main conclusions so far.

Table 4- Summary table

\begin{tabular}{lccc}
\hline & Overall & $\begin{array}{c}\text { Euro period } \\
\mathbf{1 9 9 9 - 2 0 0 3}\end{array}$ & $\begin{array}{c}\text { Euro period in } \\
\text { downswings }\end{array}$ \\
\hline Overall F.P. & Counter & Counter & Counter \\
Discretionary F.P. & Pro & Neutral & Neutral \\
\hline
\end{tabular}

Notes: See text for details. Counter refers to a counter-cyclical behaviour, and "pro" to a procyclical behaviour of fiscal policy. The conclusions for the euro period are derived from the results in Table 3.

\section{What went wrong in SGP non-compliant countries?}

If according to our results, EMU fiscal rules did not lead to a pro-cyclical fiscal policy how did Portugal, Germany, France and Greece find themselves in an excessive deficit position? According to our previous results, the most probable cause lies in the asymmetry of the use of fiscal policy over the cycle. If, in fact, the deficit is not substantially reduced during upswings, when in downswings there is no room for the full working of automatic stabilisers without breaching the 3\% reference for the deficit. As discretionary fiscal policy was not used to counteract the working of the automatic stabilisers, but evolved to a neutral stance after the introduction of the euro, the reference value was violated in countries that did not sufficiently reduced the deficit during the last upswing.

In order to find out whether our conjecture describes the reality properly we collected data on the change in the fiscal variables (expressed as ratios to GDP) during the four years of economic upswing before the start of the excessive deficit procedure. ${ }^{12}$ The results are shown in Table 6. Table 5 summarizes the ongoing excessive deficit procedures for EU15 member states. The excessive deficit procedure was initiated for five euro-area countries, and

\footnotetext{
${ }^{11}$ The results are based on a total of 60 observations of which 37 are downswings.

${ }_{12}$ Besides the three countries mentioned in the text, Greece has also been in violation of SGP dispositions since at least 2000. But this was only known in 2004, after a major statistical revision. As Greece's data is still subject to further revisions we chose not to analyse it.
} 
come to abrogation in Portugal. Italy received an early warning that was refused by the European Council. Germany and France did not follow the Council decisions.

Table 5- Ongoing excessive deficit procedures for EU15 countries

\begin{tabular}{|c|c|c|c|c|c|c|c|c|c|}
\hline & \multirow[b]{2}{*}{$\begin{array}{c}\text { Commission } \\
\text { report }\end{array}$} & \multirow[b]{2}{*}{$\begin{array}{l}\text { Council } \\
\text { decision }\end{array}$} & \multirow[b]{2}{*}{ Abrogation } & \multicolumn{6}{|c|}{ Budget deficit (\%GDP) } \\
\hline & & & & Year t & $\mathrm{t}-1$ & $\mathrm{t}$ & $\mathrm{t}+1$ & $t+2$ & $\begin{array}{c}\Delta \% \\
G D P_{t}\end{array}$ \\
\hline Portugal & $24 / 09 / 2002$ & $5 / 11 / 2002$ & $11 / 05 / 2004$ & 2001 & 2.8 & 4.4 & 2.7 & 2.8 & 1.6 \\
\hline Germany & $19 / 11 / 2002$ & $21 / 01 / 2003$ & - & 2002 & 2.8 & 3.7 & 3.8 & 3.9 & 0.1 \\
\hline France & $02 / 04 / 2003$ & $03 / 06 / 2003$ & - & 2002 & 1.5 & 3.2 & 4.1 & 3.7 & 1.2 \\
\hline NL & $28 / 04 / 2004$ & $02 / 06 / 2004$ & - & 2003 & 1.9 & 3.2 & 2.9 & 2.4 & -0.9 \\
\hline $\mathrm{UK}^{\mathrm{a})}$ & $28 / 04 / 2004$ & - & a) & 2003 & 1.7 & 3.3 & 2.8 & 2.6 & 2.2 \\
\hline Italyb) & $28 / 04 / 2004$ & b) & b) & 2004 & 2.4 & 3.0 & 3.0 & 3.6 & 1.3 \\
\hline Greece & $15 / 05 / 2004$ & 05/07/2004 & - & 2000 c) & 3.4 & 4.1 & 3.7 & 3.7 & 4.5 \\
\hline
\end{tabular}

Notes: Dates in the format dd/mm/yy. a) Commission considered the excess over the reference value "likely to be small and temporary", hence not prefiguring an excessive deficit. b) For Italy the Commission proposed an early warning that was closed by the Council in 5/7/2004. c) As noted before, the Greek excessive deficit in 2000 was only noticed in 2004 following a revised notification of deficit and debt data for 2003. According to the Eurostat report of 22/11/2004, Greece has never fulfilled the convergence criteria for entering the euro. The numbers presented in the table are still subject to further upward revisions. Values for 2004 are Commission forecasts.

Table 6- Evolution of fiscal variables in "good times"- GDP ratios

\begin{tabular}{|c|c|c|c|c|c|c|c|c|c|c|}
\hline & \multicolumn{10}{|c|}{ 1997-2000 Accumulated change in: } \\
\hline & \multicolumn{5}{|c|}{ Raw data } & \multicolumn{5}{|c|}{ Cyclically adjusted data } \\
\hline & B. Bal & $\begin{array}{c}\text { Prim. } \\
\text { Bal. }\end{array}$ & Rev. & $\begin{array}{c}\text { Prim. } \\
\text { Exp. }\end{array}$ & Interest & B. Bal. & $\begin{array}{c}\text { Prim. } \\
\text { Bal }\end{array}$ & $\operatorname{Rev}$ & $\begin{array}{c}\text { Prim. } \\
\text { Exp. }\end{array}$ & $\begin{array}{l}\text { Highest } \\
\text { B. Bal. }\end{array}$ \\
\hline Portugal & 0.8 & -0.3 & 1.1 & 1.4 & -1.0 & -0.7 & -1.7 & 0.0 & 1.8 & -3.4 a) \\
\hline Germany & 4.0 & 3.8 & 0.5 & -3.3 & -0.3 & 0.4 & 0.2 & -0.6 & -0.8 & -1.3 b) \\
\hline France & 1.6 & 1.2 & -0.7 & -1.8 & -0.5 & 0.1 & -0.4 & -1.9 & -1.5 & -2.0 b) \\
\hline
\end{tabular}

Notes: "Good times" are defined as years in which the change in the gap is positive. In both France and Germany there is a deterioration of the output gap in the year before the breach of the 3\% threshold for the deficit. a) 1997; b) 1999. Source: AMECO, Autumn 2004.

As shown in Table 6, the three early non-compliant countries present some different immediate reasons for breaching the $3 \%$ threshold, but a somewhat common pattern in the cyclically adjusted budget balance: none of them was able to reach a balanced fiscal stance during the last upswing. In contrast, other European countries were able to reach balance or even show a surplus in the cyclically adjusted budget balance in the early 2000s. ${ }^{13}$ The list of countries that present a surplus include all the Nordic countries, which are characterised by having large automatic fiscal stabilisers. It thus seems that the three first countries to show

\footnotetext{
${ }^{13}$ According to the Commission's estimates other countries reach a balanced or had a surplus fiscal stance in the following years: Austria in 2001; Belgium in 2001-2004; Denmark in 2000-2004; Finland in 2000-2004; Ireland in 2000 \& 2003; the UK in 2000-2001; Spain in 2002-2004; and Sweden in 20002004.
} 
an excessive deficit have not created enough room for the working of automatic fiscal stabilisers in downswings without causing the deficit to soar above the $3 \%$ limit.

With regard to the particular circumstances of each country, Portugal presents the smallest reduction in the deficit of all three countries considered, which is only explained by the reduction in interest outlays. It is the only one of the three countries that increased primary expenditure. Of the three, Germany shows the greatest improvement in the budget balance. However, the cyclically adjusted improvement in budget balance is just $0.4 \%$ of GDP and there is a discretionary reduction in tax revenue. The breaching of the $3 \%$ deficit limit in 2002 is mostly explained by a discretionary reduction in the tax revenue, in an attempt to counteract the slowdown of the economy. The French 3.2\% deficit in 2002 appears to be the result of important discretionary tax cuts, not accompanied by a sufficient cut in spending (the cyclically adjusted budget revenue fell by $1.9 \%$ of GDP in the 1997-2000 period).

In short, all three countries failed to move into a balanced fiscal stance during the last economic expansion, which led to a violation of the SGP's rules during the subsequent downswing in activity. These case studies thus clearly illustrate our earlier conclusion that the SGP rules are not being effectively enforced symmetrically over the cycle. Based on these results we will now derive some implications for the ongoing discussion regarding the reform of the SGP.

\section{Some implications for the reform of the SGP}

The SGP has been controversial ever since its creation. However, the criticism over its usefulness became more intense in 2002 when four euro-area economies, namely Germany, Portugal, France and Italy, had difficulties in meeting the SGP requirements. The difficulties of the two large euro-area countries in coping with the SGP requirements have also increased the political debate on the need to reform the SGP. Buti, Eijffinger and Franco (2003) present the latest comprehensive European Commission's defence on the need for just minor upgrading in the SGP provisions. Based on our previous analysis of the cyclical properties of fiscal policy we will offer some suggestions for improving the SGP provisions.

We will not address the main issue of the appropriateness of using an annual deficit ceiling to attain the long-term debt sustainability. Instead, we will focus our attention on the fact that the SGP works asymmetrically over the business cycle. The Pact enforces (at least for small countries) the $3 \%$ deficit ceiling in downturns but does nothing to prevent a procyclical deficit bias (increase in expenditure and tax cuts) during economic upswings. This in turns leaves no room for manoeuvre for the automatic stabilisers to operate during the 
periods of slow or negative growth that might follow. Consequently, in order not to breach the 3\% deficit ceiling, governments that have previously opted for a pro-cyclical behaviour must continue to follow a pro-cyclical fiscal policy retrenchment during recessions, counteracting the working of the automatic stabilisers and extending the length of the periods of slow growth. Recent events in Portugal are a good example of such behaviour.

To prevent the SGP from giving a wrong incentive for (some) countries to continue to pursue pro-cyclical fiscal policies, the SGP rules must be made symmetric over the cycle, binding both in upswings and downturns. To accomplish this, it is necessary to "force" governments to cut deficits during economic upswings, resisting tax cuts and expenditure increases when the economy is growing. This clearly requires that the yearly definition of the appropriate deficit target is made by an independent technical body. There are however several practical difficulties involved:

a) First, such an exercise implicitly requires the calculation of the cyclically adjusted budget balances (fiscal stance). This calculation is not straightforward. Firstly, it requires several assumptions on the elasticity of the budget variables to the cycle. ${ }^{14}$ Secondly, it requires the correct estimation of the precise phase of the business cycle that the economy is in. Due to the known limitations of the widely used filters, such as the end-point bias of the Hodrick-Prescott filter, the calculation of the output gap for the current year is subject to very important revisions when new data becomes available. So this technical difficulty of properly identifying the actual position of the business cycle, makes it difficult to set a concrete deficit target on an annual basis. Nevertheless, such calculations do give an important sign of the road to follow.

b) In order to "politically force" governments to comply with such technical budget deficit targets, the calculation must be done by an independent and technically credible body. Possible candidates are the European Commission or the creation of independent (technical) fiscal policy councils at national level. The subsidiarity principle and political resistance to increasing the Commission's powers, makes it politically more viable to grant such powers to independent national councils. See for instance the recent proposals for "National Fiscal Councils" by Eichengreen, Hausman and Von Hagen (1999), "Fiscal Policy Committees" by Wyplosz (2002) or a "Wise Persons Committee" by Pina (2004). The proposals differ in the amount of fiscal power delegated to the committees, but they agree on the mandate for ensuring debt sustainability.

c) The enforcement of such targets is a clear political problem. Traditionally the tax and spending power is in the jurisdiction of national Parliaments. Political agents will resist anything that might limit their ability to influence the political business cycle, making the enforcement of such arrangement a very delicate issue. Then again, a "name and shame"

${ }^{14}$ See Van Den Noord (2002) for a discussion on the limitation of OECD calculations. 
strategy by the independent technical councils relative to undisciplined governments will certainly make fiscal policy work better than in current arrangements.

To sum up, it is very difficult to remove political considerations from the operation of fiscal policy, which is the only macroeconomic instrument still in the control of national governments. It is not politically conceivable that fiscal policy will be delegated to an independent institution, mimicking the (successful) conduct of monetary policy in the recent years. However, from an economic point of view it is desirable that fiscal policy should work as a counter-cyclical device, smoothing output fluctuations, especially the fluctuations due to asymmetric demand shocks. Therefore, it is necessary that fiscal policy works symmetrically over the cycle, decreasing the budget balance (increasing the deficit) during "bad times" and increasing it during "good times". Put differently, room has to be created for manoeuvre so that the automatic fiscal stabilisers can work freely over the full business cycle. To increase the probability of such an outcome, a deficit target based on these technical considerations should be announced by an independent trusted body, and this should be incorporated in the next reform of the SGP.

\section{Concluding remarks}

We have analysed the cyclical properties of fiscal policy for a panel of 12 European Union countries over the period 1980-2003. We conclude that the overall budget balance has been counter-cyclical. In contrast, discretionary fiscal policy is found to be pro-cyclical, reducing the effectiveness of the automatic stabilisers at smoothing output fluctuations.

We conclude that the operation of the fiscal rules of the EMU, namely, the SGP provisions, has improved the counter-cyclical properties of fiscal policy, especially during downswings in economic activity. In the period following the introduction of the euro, discretionary fiscal policy has ceased to be pro-cyclical, reinforcing the counter-cyclical behaviour of fiscal policy. This is an interesting result that goes against what might have been expected. However, we should point out that some care is needed in the interpretation of this result, since the time period is still short. Moreover, the validity of this result for the ensemble of the 12 countries examined does not imply its validity in each of them individually.

All in all, EMU fiscal rules had a positive impact on the counter-cyclical properties of fiscal policy. However, our results also show that such rules are not being symmetrically applied over the cycle. This means that fiscal policy is more expansive in downswings than it is tightened in upswings. This is a serious reason for concern because this behaviour leads to an insufficient deficit reduction in "good times", thus failing to create room for the full operation of automatic stabilisers in "bad times", unless countries do not comply with the 
$3 \%$ deficit ceiling or resort to one-off measures. The case studies of Portugal, Germany and France illustrate our concern. In our view, the breaching of the deficit limit by these countries was the result of an insufficient improvement in the fiscal stance during the previous economic upswing: unlike other countries, none of these three countries reached a balanced fiscal stance in the early 2000s.

Based on the above conclusions, we have derived implications for the ongoing debate on the reform of the SGP. We argue that special attention should be given to making the SGP rules symmetric over the cycle, binding in both upswings and downturns. In order to achieve such an outcome we favour the creation of independent (technical) fiscal policy councils at national level that would set the appropriate deficit targets on an annual basis. The purpose would be to ensure debt sustainability, while simultaneously permitting the symmetric behaviour of fiscal policy over the cycle, creating room for the operation of the automatic fiscal stabilisers.

\section{References}

ANDERsen, T. M. (2001), "Stabilization Policy", University of Aarhus, unpublished manuscript, June.

AUERBACH, A. J. (2002), "Is There a Role for Discretionary Fiscal Policy?", NBER Working Paper, No. 9306.

Baltagi, B. H. (2001), Econometric Analysis of Panel Data, $2^{\text {nd }}$ edition, Chichester: John Wiley \& Sons.

BAYOUMI, T. and P. R. MASsON (1995), "Fiscal Flows in the United States and Canada: lessons for monetary union in Europe", European Economic Review, 39, 253-274.

BUTI, M., S. EIJFFINGER and D. FRANCO (2003), "Revisiting the Stability and Growth Pact: grand design or internal adjustment", European Economy, European Commission Economic Papers, No. 180, January.

EICHENGReEN, B., R. HAUSMAN and J. VON HAgEN (1999), "Reforming Budgetary Institutions in Latin America: the case for a National Fiscal Council", Open Economies Review, 10, 415-442.

EUROPEAN COMMISSION (2004), "Cyclical Adjustment of Budget Balances", ECFIN/175/2004EN, Autumn. http://europa.eu.int/comm/economy finance/index en.htm.

LANE, P. R. (2003), "The Cyclical Behaviour of Fiscal Policy: evidence from the OECD", Journal of Public Economics, 87(12), 2661-2675.

MARINHeIRO, C. (2003), EMU and Fiscal Stabilisation Policy: the case of small countries, Ph.D. dissertation, No. 179, Leuven: Katholieke Universiteit Leuven.

OECD (2003), "Fiscal Stance Over the Cycle: the role of debt, institutions, and budget constraints", OECD Economic Outlook, 74(Chapter IV), December.

PINA, Á. (2004), Fiscal Policy in Portugal: Discipline, Cyclicality and the Scope for Expenditure Rules, proceedings of the 2nd Conference on Portuguese Economic Development in the European Context, held by the Bank of Portugal in Lisbon, 11-12 March 2004, forthcoming. 
VAN Den Noord, P. (2002), "Automatic Stabilisers in the 1990s and Beyond" in M. Buti, J. von Hagen and C. Martinez-Mongay (eds.), The Behaviour of Fiscal Authorities, Palgrave, Chapter 8.

WYPLOSZ, C. (2002), "Fiscal Discipline in EMU: Rules or Institutions?", Paper prepared for the April 16, 2002 meeting of the Group of Economic Analysis of the European Commission. http://heiwww.unige.ch/ wyplosz/. 


\section{EsTUDOS DO G.E.M.F.}

(Available on-line at http://gemf.fe.uc.pt)

2005-02 Has the Stability and Growth Pact stabilised? Evidence from a panel of 12 European countries and some implications for the reform of the Pact

- Carlos Fonseca Marinheiro

2005-01 Sustainability of Portuguese Fiscal Policy in Historical Perspective

- Carlos Fonseca Marinheiro

2004-03 Human capital, mechanisms of technological diffusion and the role of technological shocks in the speed of diffusion. Evidence from a panel of Mediterranean countries

- Maria Adelaide Duarte e Marta Simões

2004-02 What Have We Learned About The Employment Effects of Severance Pay? Further Iterations of Lazear et al.

- John T. Addison e Paulino Teixeira

2004-01 How the Gold Standard Functioned in Portugal: an analysis of some macroeconomic aspects - António Portugal Duarte e João Sousa Andrade

2003-07 Testing Gibrat's Law: Empirical Evidence from a Panel of Portuguese Manufacturing Firms - Blandina Oliveira e Adelino Fortunato

2003-06 Régimes Monétaires et Théorie Quantitative du Produit Nominal au Portugal (1854-1998) - João Sousa Andrade

2003-05 Causas do Atraso na Estabilização da Inflação: Abordagem Teórica e Empírica - Vítor Castro

2003-04 The Effects of Households' and Firms' Borrowing Constraints on Economic Growth - Maria da Conceição Costa Pereira

2003-03 Second Order Filter Distribution Approximations for Financial Time Series with Extreme Outliers

- J. Q. Smith e António A. F. Santos

2003-02 Output Smoothing in EMU and OECD: Can We Forego Government Contribution? A risk sharing approach

- Carlos Fonseca Marinheiro

2003-01 Um modelo VAR para uma Avaliação Macroeconómica de Efeitos da Integração Europeia da Economia Portuguesa

- João Sousa Andrade

2002-08 Discrimination des facteurs potentiels de croissance et type de convergence de l'économie portugaise dans l'UE à travers la spécification de la fonction de production macro-économique. Une étude appliquée de données de panel et de séries temporelles

- Marta Simões e Maria Adelaide Duarte 
2002-07 Privatisation in Portugal: employee owners or just happy employees?

-Luís Moura Ramos e Rita Martins

2002-06 The Portuguese Money Market: An analysis of the daily session

- Fátima Teresa Sol Murta

2002-05 As teorias de ciclo políticos e o caso português

- Rodrigo Martins

2002-04 Fundos de acções internacionais: uma avaliação de desempenho

- Nuno M. Silva

2002-03 The consistency of optimal policy rules in stochastic rational expectations models

- David Backus and John Driffill

2002-02 The term structure of the spreads between Portuguese and German interest rates during stage II of EMU

- José Soares da Fonseca

2002-01 O processo desinflacionista português: análise de alguns custos e benefícios

- António Portugal Duarte

2001-14 Equity prices and monetary policy: an overview with an exploratory model

- Fernando Alexandre e Pedro Bação

2001-13 A convergência das taxas de juro portuguesas para os níveis europeus durante a segunda metade da década de noventa

- José Soares da Fonseca

2001-12 Le rôle de l'investissement dans l'éducation sur la croissance selon différentes spécifications du capital humain.

- Adelaide Duarte e Marta Simões

2001-11 Ricardian Equivalence: An Empirical Application to the Portuguese Economy

- Carlos Fonseca Marinheiro

2001-10 A Especificação da Função de Produção Macro-Económica em Estudos de Crescimento Económico.

- Maria Adelaide Duarte e Marta Simões

2001-09 Eficácia da Análise Técnica no Mercado Accionista Português

- Nuno Silva

2001-08 The Risk Premiums in the Portuguese Treasury Bills Interest Rates: Estimation by a cointegration method

- José Soares da Fonseca

2001-07 Principais factores de crescimento da economia portuguesa no espaço europeu

- Maria Adelaide Duarte e Marta Simões

2001-06 Inflation Targeting and Exchange Rate Co-ordination

- Fernando Alexandre, John Driffill e Fabio Spagnolo

2001-05 Labour Market Transition in Portugal, Spain, and Poland: A Comparative Perspective

- Paulino Teixeira 
2001-04 Paridade do Poder de Compra e das Taxas de Juro: Um estudo aplicado a três países da UEM - António Portugal Duarte

2001-03 Technology, Employment and Wages

- John T. Addison e Paulino Teixeira

2001-02 Human capital investment through education and economic growth. A panel data analysis based on a group of Latin American countries

- Maria Adelaide Duarte e Marta Simões

2001-01 Risk Premiums in the Porutguese Treasury Bills Interest Rates from 1990 to 1998. An ARCHM Approach

- José Soares da Fonseca

2000-08 Identificação de Vectores de Cointegração: Análise de Alguns Exemplos

- Pedro Miguel Avelino Bação

2000-07 Imunização e M-quadrado: Que relação?

- Jorge Cunha

2000-06 Eficiência Informacional nos Futuros Lisbor 3M

- Nuno M. Silva

2000-05 Estimation of Default Probabilities Using Incomplete Contracts Data

- J. Santos Silva e J. Murteira

2000-04 Un Essaie d'Application de la Théorie Quantitative de la Monnaie à l'économie portugaise, 1854-1998

- João Sousa Andrade

2000-03 Le Taux de Chômage Naturel comme un Indicateur de Politique Economique? Une application à l'économie portugaise

- Adelaide Duarte e João Sousa Andrade

2000-02 La Convergence Réelle Selon la Théorie de la Croissance: Quelles Explications pour l'Union Européenne?

- Marta Cristina Nunes Simões

2000-01 Política de Estabilização e Independência dos Bancos Centrais

- João Sousa Andrade

1999-09 Nota sobre a Estimação de Vectores de Cointegração com os Programas CATS in RATS,

PCFIML e EVIEWS

- Pedro Miguel Avelino Bação

1999-08 A Abertura do Mercado de Telecomunicações Celulares ao Terceiro Operador: Uma Decisão Racional?

- Carlos Carreira

1999-07 Is Portugal Really so Arteriosclerotic? Results from a Cross-Country Analysis of Labour Adjustment

- John T. Addison e Paulino Teixeira 
1999-06 The Effect of Dismissals Protection on Employment: More on a Vexed Theme - John T. Addison, Paulino Teixeira e Jean-Luc Grosso

1999-05 A Cobertura Estática e Dinâmica através do Contrato de Futuros PSI-20. Estimação das Rácios e Eficácia Ex Post e Ex Ante

- Helder Miguel C. V. Sebastião

1999-04 Mobilização de Poupança, Financiamento e Internacionalização de Carteiras - João Sousa Andrade

1999-03 Natural Resources and Environment

- Adelaide Duarte

1999-02 L'Analyse Positive de la Politique Monétaire

- Chistian Aubin

1999-01 Economias de Escala e de Gama nos Hospitais Públicos Portugueses: Uma Aplicação da Função de Custo Variável Translog

- Carlos Carreira

1998-11 Equilíbrio Monetário no Longo e Curto Prazos - Uma Aplicação à Economia Portuguesa - João Sousa Andrade

1998-10 Algumas Observações Sobre o Método da Economia - João Sousa Andrade

1998-09 Mudança Tecnológica na Indústria Transformadora: Que Tipo de Viés Afinal?

- Paulino Teixeira

1998-08 Portfolio Insurance and Bond Management in a Vasicek's Term Structure of Interest Rates - José Alberto Soares da Fonseca

1998-07 Financial Innovation and Money Demand in Portugal: A Preliminary Study

- Pedro Miguel Avelino Bação

1998-06 The Stability Pact and Portuguese Fiscal Policy: the Application of a VAR Model - Carlos Fonseca Marinheiro

1998-05 A Moeda Única e o Processo de Difusão da Base Monetária - José Alberto Soares da Fonseca

1998-04 La Structure par Termes et la Volatilité des Taux d'intérêt LISBOR - José Alberto Soares da Fonseca

1998-03 Regras de Comportamento e Reformas Monetárias no Novo SMI - João Sousa Andrade

1998-02 Um Estudo da Flexibilidade dos Salários: o Caso Espanhol e Português

- Adelaide Duarte e João Sousa Andrade

1998-01 Moeda Única e Internacionalização: Apresentação do Tema - João Sousa Andrade

1997-09 Inovação e Aplicações Financeiras em Portugal - Pedro Miguel Avelino Bação 
1997-08 Estudo do Efeito Liquidez Aplicado à Economia Portuguesa

- João Sousa Andrade

1997-07 An Introduction to Conditional Expectations and Stationarity

- Rui Manuel de Almeida

1997-06 Definição de Moeda e Efeito Berlusconi

- João Sousa Andrade

1997-05 A Estimação do Risco na Escolha dos Portafólios: Uma Visão Selectiva

- António Alberto Ferreira dos Santos

1997-04 A Previsão Não Paramétrica de Taxas de Rentabilidade

- Pedro Manuel Cortesão Godinho

1997-03 Propriedades Assimptóticas de Densidades

- Rui Manuel de Almeida

1997-02 Co-Integration and VAR Analysis of the Term Structure of Interest Rates: an empirical study of the Portuguese money and bond markets

-João Sousa Andrade e José Soares da Fonseca

1997-01 Repartição e Capitalização. Duas Modalidades Complementares de Financiamento das Reformas

- Maria Clara Murteira

1996-08 A Crise e o Ressurgimento do Sistema Monetário Europeu

- Luis Manuel de Aguiar Dias

1996-07 Housing Shortage and Housing Investment in Portugal a Preliminary View

- Vítor Neves

1996-06 Housing, Mortgage Finance and the British Economy

- Kenneth Gibb e Nile Istephan

1996-05 The Social Policy of The European Community, Reporting Information to Employees, a U.K. perspective: Historical Analysis and Prognosis

- Ken Shackleton

1996-04 O Teorema da Equivalência Ricardiana: aplicação à economia portuguesa

- Carlos Fonseca Marinheiro

1996-03 O Teorema da Equivalência Ricardiana: discussão teórica

- Carlos Fonseca Marinheiro

1996-02 As taxas de juro no MMI e a Restrição das Reservas Obrigatórias dos Bancos

- Fátima Assunção Sol e José Alberto Soares da Fonseca

1996-01 Uma Análise de Curto Prazo do Consumo, do Produto e dos Salários

- João Sousa Andrade 